\title{
Effects of water deprivation on the Mongolian gerbil, Meriones unguiculatus: Absence of Harderian gland involvement
}

\author{
DEL THIESSEN \\ University of Texas, Austin, Texas 78712
}

\begin{abstract}
Seven days of water deprivation depressed a number of physiological and behavioral functions in Harderianectomized and intact Meriones unguiculatus. Body weight, food ingestion, general activity, ventral scent gland marking, scent gland size, facial grooms, urination, and defecation were all reduced when water was unavailable. The effects were reversed within 7 days when water was restored. The absence of the Harderian gland does not modify the reactions to dehydration.
\end{abstract}

The orbital Harderian gland of Meriones unguiculatus releases a pigment- and lipid-rich substance at the nares of the nose during a thermoregulatory groom (Thiessen, 1977). The material is spread widely on the face and pelage, functioning both as a chemoattractant and as a mechanical insulator against cold and dampness (Thiessen \& Kittrell, 1980). Harderianectomy eliminates these functions. A comparable chemoattractant function for Harderian material has been reported for the hamster by Payne (1977).

To date, the effects of Harderianectomy in the gerbil appear to result from a direct loss of the secretory material. However, undetected physiological changes could be influencing our results. We have begun a series of studies to assess this possibility. In this experiment, we test the effects of water deprivation in Harderianectomized and intact gerbils on a number of open-field behaviors and morphological traits. Water deprivation places a severe stress on metabolic and reproductive processes of the Mongolian gerbil (Yahr \& Kessler, 1975) and might be expected to unveil physiological consequences of Harderianectomy for these as well as other processes. Such inquiry is warranted, given the current lack of evidence for any physiological influence of the Harderian gland (Kennedy, 1970).

\section{METHOD}

\section{Animals}

Twenty adult male gerbils (150 days or older), purchased from Tumblebrook Farms, West Brookfield, Massachusetts, were used in this study. The animals were individually housed in polyethylene cages $(28 \times 19 \times 13 \mathrm{~cm})$ with pine shavings as bedding. Prior to the deprivation phase of the experiment, all animals were fed Purina Lab Chow and given tap water ad lib. A 12-12 light-dark

This research was supported by NIMH Research Grant MH 14076-13. Appreciation is extended to David Bean, who assisted in this study. cycle was maintained throughout the experiment. Colony temperature was constant at about $25.9^{\circ} \mathrm{C}$ and relative humidity was about $50 \%$.

\section{Surgical Treatment}

Two groups of animals of approximately equal body weight were formed. One group was Harderianectomized according to the procedure described by Thiessen, Clancy, and Goodwin (1976), and the other group received control operations. Briefly, each operation was performed by anesthetizing the animal with Nembutal $(.09 \mathrm{ml})$, cutting the nictitating membrane at the anterior corner of the eye, and removing the gland with forceps. The control operation involved cutting the membrane but leaving the gland in situ. The operations were performed bilaterally in less than $2 \mathrm{~min}$. The animals were allowed at least 3 weeks to recover from the operation. During this period, the pelage became lighter in color and lost at least $40 \%$ of its lipids (Thiessen \& Kittrell, 1980).

\section{Test Apparatus}

A gray wooden open field (1 $\mathrm{m}^{2}$, with walls $65 \mathrm{~cm}$ high) was used to assess general activity, ventral scent marking, facial grooms, urine deposits, and defecation. The floor of the open field was divided by black lines into 60 equal-sized squares. A Plexiglas peg $(2.6 \times 1.2 \times .7 \mathrm{~cm})$ was glued to the floor at each of the nine lined intersections. Gerbils direct their ventral scent marking at these pegs. Fluorescent ceiling lights illuminated the open field.

\section{Procedure}

The experiment was conducted in three successive blocks of 7 days each. Responses were recorded for the last 5 days of each block. During the first block, tap water was available through a drinking spout ad lib. During the second block, water was withheld. Finally, during the third block, water was reinstated. Food was available at all times.

During each of the three successive blocks, records were taken on the following measures: body weight, food ingestion, and open-field responses. Measurements were taken during the light phase of a 12-12 light-dark cycle. Body weight was recorded to the nearest $.1 \mathrm{~g}$, and food consumption was weighed to the nearest $.01 \mathrm{~g}$ (weight difference of preweighed Purina Lab Chow pellets presented in the animal's cage every $24 \mathrm{~h}$ ).

Following these recordings, the gerbils were individually transported to the testing room and were allowed $15 \mathrm{~min}$ in the open field. Behavioral testing was conducted during the first half of the light-dark cycle. Every other animal tested was Harderianectomized, and each animal was tested at the same time each day. For each test, the animal was removed from its home cage and placed in one corner of the open field. Activity was recorded by 

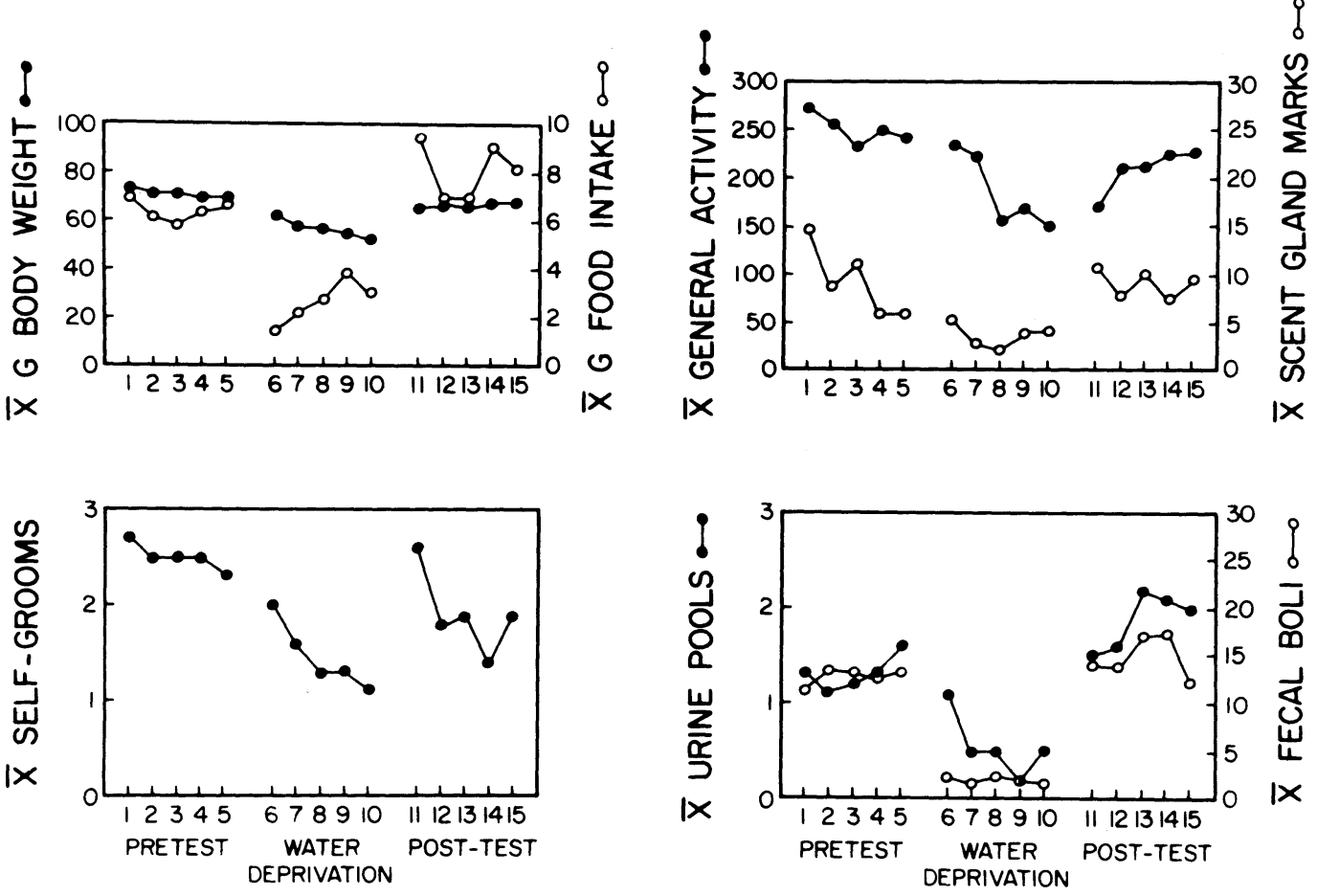

DAYS OF TESTING

DAYS OF TESTING

HARDERIANECTOMIZED GERBILS
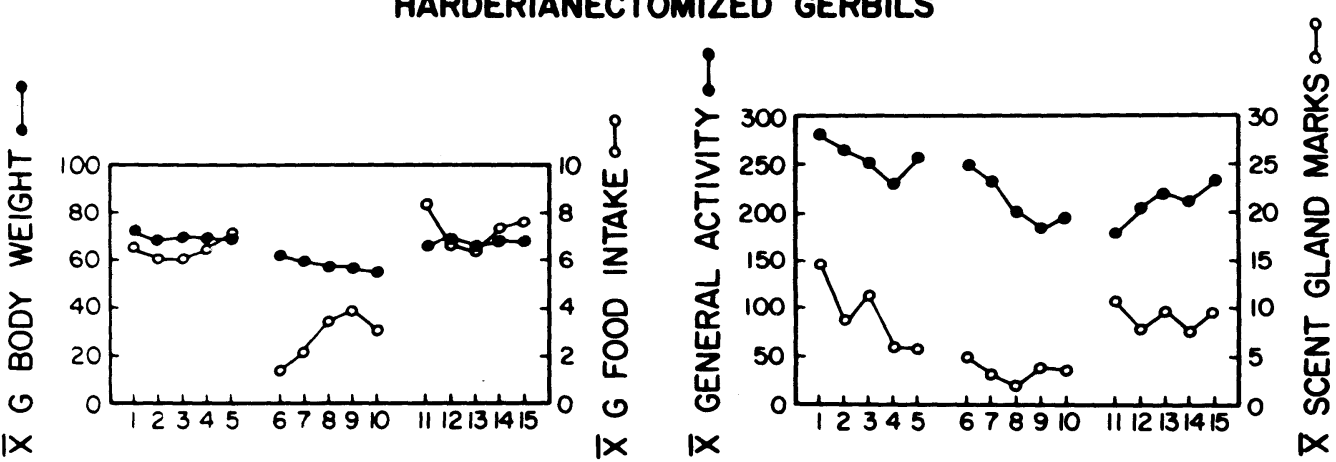

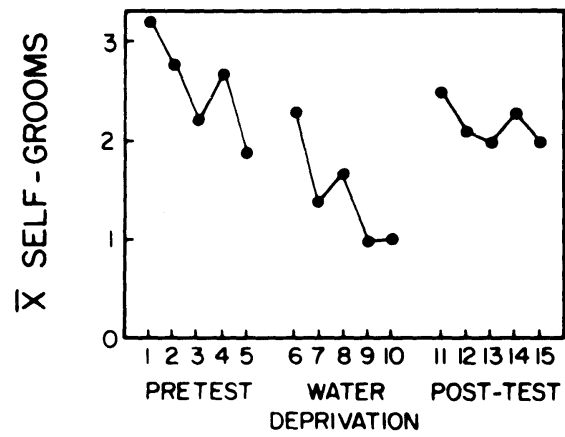

DAYS OF TESTING

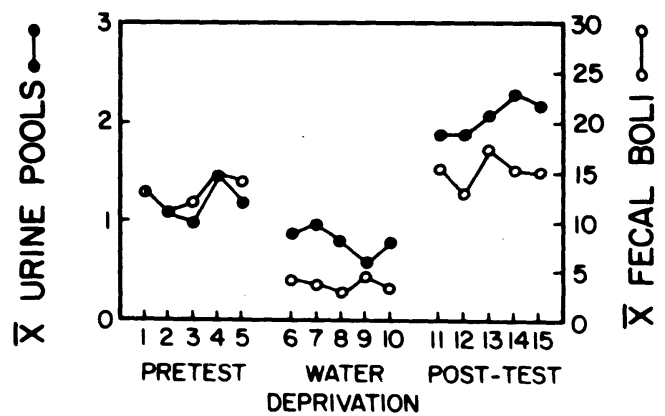

DAYS OF TESTING

Figure 1. Effects of water availability on physiological and behavioral functions of sham-operated and Harderianectomized male Mongolian gerbils. 
Table 1

Results of Water Deprivation Study

\begin{tabular}{|c|c|c|c|c|c|c|c|}
\hline Condition & $\begin{array}{c}\text { Harderian } \\
\text { Status }\end{array}$ & Mean $\pm \mathrm{SE}$ & F: Condition & $\begin{array}{c}\mathrm{F}: \text { Harderian } \\
\text { Status** }\end{array}$ & $\begin{array}{l}\text { Newman-Keuls } \\
\text { Comparison }\end{array}$ & $\begin{array}{l}\text { F: Linear Trend } \\
\text { Condition* }\end{array}$ & $\begin{array}{c}\text { F: Quadratic } \\
\text { Trend } \\
\text { Condicion* }\end{array}$ \\
\hline \multicolumn{8}{|c|}{ Body Weight (g) } \\
\hline Pretest & $\begin{array}{l}\text { Hard X } \\
\text { Sham }\end{array}$ & $\begin{array}{l}70.9 \pm 2.3 \\
72.0 \pm 2.3\end{array}$ & & & $\begin{array}{l}\text { Pretest-Deprivation } \\
\mathrm{p}<.01\end{array}$ & & \\
\hline Deprivation & $\begin{array}{l}\text { Hard X } \\
\text { Sham }\end{array}$ & $\begin{array}{l}59.2 \pm 1.8 \\
57.8 \pm 2.1\end{array}$ & $\begin{array}{l}438.17 \\
\mathrm{p}<.001\end{array}$ & $\begin{array}{l}.00 \\
p=.96\end{array}$ & $\begin{array}{l}\text { Pretest-Posttest } \\
\mathrm{p}<.01\end{array}$ & $\begin{array}{l}135.64 \\
\mathrm{p}<.001\end{array}$ & $\begin{array}{l}14.37 \\
\mathrm{p}<.001\end{array}$ \\
\hline Posttest & $\begin{array}{l}\text { Hard X } \\
\text { Sham }\end{array}$ & $\begin{array}{l}68.4 \pm 2.1 \\
68.2 \pm 2.0\end{array}$ & & & $\begin{array}{l}\text { Deprivation-Posttest } \\
\mathrm{p}<.01\end{array}$ & & \\
\hline \multicolumn{8}{|c|}{ Food Intake (g/day) } \\
\hline Pretest & $\begin{array}{l}\text { Hard X } \\
\text { Sham }\end{array}$ & $\begin{array}{l}6.6 \pm 0.5 \\
6.4 \pm 0.3\end{array}$ & & & $\begin{array}{l}\text { Pretest-Deprivation } \\
\mathrm{p}<.01\end{array}$ & & \\
\hline Deprivation & $\begin{array}{l}\text { Hard X } \\
\text { Sham }\end{array}$ & $\begin{array}{l}2.9 \pm 0.2 \\
2.8 \pm 0.2\end{array}$ & $\begin{array}{l}260.77 \\
p<.001\end{array}$ & $\begin{array}{l}.22 \\
p=.64\end{array}$ & $\begin{array}{l}\text { Pretest-Posttest } \\
\mathrm{p}<.01\end{array}$ & $\begin{array}{c}10.62 \\
p<.001\end{array}$ & $\begin{array}{l}22.93 \\
p<.001\end{array}$ \\
\hline Posttest & $\begin{array}{l}\text { Hard X } \\
\text { Sham }\end{array}$ & $\begin{array}{l}7.4 \pm 0.4 \\
8.2 \pm 0.3\end{array}$ & & & $\begin{array}{l}\text { Deprivation-Postest } \\
\mathrm{p}<.01\end{array}$ & & \\
\hline \multicolumn{8}{|c|}{ General Activity (15 min) } \\
\hline Pretest & $\begin{array}{l}\text { Hard X } \\
\text { Sham }\end{array}$ & $\begin{array}{l}258.7 \pm 14.2 \\
252.1 \pm 20.9\end{array}$ & & & $\begin{array}{l}\text { Pretest-Deprivation } \\
\mathrm{p}<.01\end{array}$ & & \\
\hline Deprivation & $\begin{array}{l}\text { Hard X } \\
\text { Sham }\end{array}$ & $\begin{array}{l}216.0 \pm 16.2 \\
186.9 \pm 23.4\end{array}$ & $\begin{array}{c}15.74 \\
p<.001\end{array}$ & $\begin{array}{l}.27 \\
\mathrm{p}=.61\end{array}$ & $\begin{array}{l}\text { Pretest-Posttest } \\
\mathrm{p}<.01\end{array}$ & $\begin{array}{c}19.95 \\
\mathrm{p}<.001\end{array}$ & $\begin{array}{c}4.81 \\
p=.01\end{array}$ \\
\hline Posttest & $\begin{array}{l}\text { Hard X } \\
\text { Sham }\end{array}$ & $\begin{array}{l}212.7 \pm 9.7 \\
209.3 \pm 27.0\end{array}$ & & & $\begin{array}{l}\text { Deprivation-Posttest } \\
\mathrm{p}<.05\end{array}$ & & \\
\hline \multicolumn{8}{|c|}{ Scent Gland Marking (15 min) } \\
\hline Pretest & $\begin{array}{l}\text { Hard X } \\
\text { Sham }\end{array}$ & $\begin{array}{r}9.4 \pm 3.1 \\
10.3 \pm 5.1\end{array}$ & & & $\begin{array}{l}\text { Pretest-Deprivation } \\
\mathrm{p}<.01\end{array}$ & & \\
\hline Deprivation & $\begin{array}{l}\text { Hard X } \\
\text { Sham }\end{array}$ & $\begin{array}{l}3.9 \pm 1.2 \\
2.5 \pm 0.5\end{array}$ & $\begin{array}{c}6.84 \\
p=.003\end{array}$ & $\begin{array}{l}.01 \\
\mathrm{p}=.93\end{array}$ & $\begin{array}{l}\text { Pretest-Posttest } \\
\mathrm{p}>.05\end{array}$ & $\begin{array}{c}8.66 \\
p=.001\end{array}$ & $\begin{array}{c}.67 \\
p=.45\end{array}$ \\
\hline Posttest & $\begin{array}{l}\text { Hard X } \\
\text { Sham }\end{array}$ & $\begin{array}{l}9.2 \pm 2.6 \\
8.8 \pm 2.8\end{array}$ & & & $\begin{array}{l}\text { Deprivation-Posttest } \\
\mathrm{p}<.01\end{array}$ & & \\
\hline \multicolumn{8}{|c|}{ Facial Grooms (15 min) } \\
\hline Pretest & $\begin{array}{l}\text { Hard X } \\
\text { Sham }\end{array}$ & $\begin{array}{l}2.6 \pm 0.2 \\
2.5 \pm 0.1\end{array}$ & & & $\begin{array}{l}\text { Pretest-Deprivation } \\
\mathrm{p}<.01\end{array}$ & & \\
\hline Deprivation & $\begin{array}{l}\text { Hard X } \\
\text { Sham }\end{array}$ & $\begin{array}{l}1.5 \pm 0.2 \\
1.5 \pm 0.1\end{array}$ & $\begin{array}{c}46.06 \\
p<.001\end{array}$ & $\begin{array}{l}.34 \\
p=.56\end{array}$ & $\begin{array}{l}\text { Pretest-Posttest } \\
\mathrm{p}<.01\end{array}$ & $\begin{array}{r}1.88 \\
p=.17\end{array}$ & $\begin{array}{c}.42 \\
p=.66\end{array}$ \\
\hline Posttest & $\begin{array}{l}\text { Hard X } \\
\text { Sham }\end{array}$ & $\begin{array}{l}2.2 \pm 0.2 \\
1.9 \pm 0.2\end{array}$ & & & $\begin{array}{l}\text { Deprivation Posttest } \\
\mathrm{p}<.01\end{array}$ & & \\
\hline \multicolumn{8}{|c|}{ Urine Marks (15 min) } \\
\hline Pretest & $\begin{array}{l}\text { Hard X } \\
\text { Sham }\end{array}$ & $\begin{array}{l}1.2 \pm 0.1 \\
1.3 \pm 0.1\end{array}$ & & & $\begin{array}{l}\text { Pretest-Deprivation } \\
\mathrm{p}<.01\end{array}$ & & \\
\hline Deprivation & $\begin{array}{l}\text { Hard X } \\
\text { Sham }\end{array}$ & $\begin{array}{l}0.8 \pm 0.1 \\
0.6 \pm 0.1\end{array}$ & $\begin{array}{c}36.30 \\
\mathrm{p}<.001\end{array}$ & $\begin{array}{l}.45 \\
\mathrm{p}=.51\end{array}$ & $\begin{array}{l}\text { Pretest-Posttest } \\
\mathrm{p}<.01\end{array}$ & $\begin{array}{c}3.45 \\
p=.04\end{array}$ & $\begin{array}{c}.14 \\
\mathrm{p}=.71\end{array}$ \\
\hline Posttest & $\begin{array}{l}\text { Hard X } \\
\text { Sham }\end{array}$ & $\begin{array}{l}2.1 \pm 0.2 \\
1.9 \pm 0.3\end{array}$ & & & $\begin{array}{l}\text { Deprivation-Posttest } \\
\mathrm{p}<.01\end{array}$ & & \\
\hline \multicolumn{8}{|c|}{ Defecation (15 $\mathrm{min})$} \\
\hline Pretest & $\begin{array}{l}\text { Hard X } \\
\text { Sham }\end{array}$ & $\begin{array}{l}13.0 \pm 1.4 \\
12.8 \pm 0.5\end{array}$ & & & $\begin{array}{l}\text { Pretest-Deprivation } \\
\mathrm{p}<.01\end{array}$ & & \\
\hline Deprivation & $\begin{array}{l}\text { Hard X } \\
\text { Sham }\end{array}$ & $\begin{array}{l}3.9 \pm 1.0 \\
1.9 \pm 0.6\end{array}$ & $\begin{array}{l}264.99 \\
p<.001\end{array}$ & $\begin{array}{l}.54 \\
p=.47\end{array}$ & $\begin{array}{l}\text { Pretest-Posttest } \\
\mathrm{p}<.01\end{array}$ & $\begin{array}{c}1.16 \\
p=.33\end{array}$ & $\begin{array}{c}3.14 \\
p=.09\end{array}$ \\
\hline Posttest & $\begin{array}{l}\text { Hard X } \\
\text { Sham }\end{array}$ & $\begin{array}{l}15.3 \pm 1.0 \\
15.0 \pm 0.6\end{array}$ & & & $\begin{array}{l}\text { Deprivation-Posttest } \\
\mathrm{p}<.01\end{array}$ & & \\
\hline \multicolumn{8}{|c|}{ Ventral Scent Gland $(1 \times \mathrm{w}$ in $\mathrm{cm})$} \\
\hline Pretest & $\begin{array}{l}\text { Hard X } \\
\text { Sham }\end{array}$ & $\begin{array}{l}1.2 \pm 0.1 \\
1.2 \pm 0.1\end{array}$ & & & $\begin{array}{l}\text { Pretest-Deprivation } \\
\mathrm{p}<.01\end{array}$ & & \\
\hline Deprivation & $\begin{array}{l}\text { Hard X } \\
\text { Sham }\end{array}$ & $\begin{array}{l}0.7 \pm 0.1 \\
0.7 \pm 0.1\end{array}$ & $\begin{array}{c}30.32 \\
\mathrm{p}<.001\end{array}$ & $\begin{array}{l}.11 \\
p=.74\end{array}$ & $\begin{array}{l}\text { Pretest-Posttest } \\
\mathrm{p}>.05\end{array}$ & & \\
\hline Posttest & $\begin{array}{l}\text { Hard X } \\
\text { Sham }\end{array}$ & $\begin{array}{l}1.2 \pm 0.1 \\
1.1 \pm 0.1 \\
\end{array}$ & & & $\begin{array}{l}\text { Deprivation-Posttest } \\
\mathrm{p}<.01\end{array}$ & & \\
\hline
\end{tabular}

$* d f=2$ and $36 . \quad * * d f=1$ and 18 . 
counting the number of line crossings during the test period (movement of both forelimbs across a line). A ventral scent mark was recorded each time a gerbil lowered its abdominal gland onto one of the Plexiglas pegs. In addition, the number of facial grooms was recorded. A facial groom was defined as a stereotyped paw scrubbing of the face and head associated with a rapid eye blink. At the termination of the 15-min trial, the animal was returned to its home cage and placed back in the colony room, and the number of urine pools and fecal boli in the field was counted. The open field was cleaned between trials with a $50 \%$ ethanol-water solution. On the last day of each test block, and after the behavioral test, the ventral scent gland was measured ( $1 \times$ width in centimeters) because the size of the gland is an index of androgen secretion (Thiessen \& Rice, 1976).

Analyses of variance and trend analyses for repeated measures were conducted for the two groups under the three water conditions for each measure, followed by Newman-Keuls comparisons across conditions. Limited measures on the ventral scent gland did not permit trend analyses.

\section{RESULTS}

The effects of water deprivation on Harderianectomized and intact gerbils can be seen in Figure 1 and in Table 1, where the statistics are summarized. Water deprivation depresses body weight, food intake, general activity, scent gland marking, grooming, urination, and defecation. Scent gland size is also reduced by dehydration. When water is restored, all measures approach predeprivation levels within 7 days.

While watet deprivation decreases every measure, there are no differential effects due to Harderian gland status. Both the quantitative variations and the pattern over trials across conditions are highly similar.

\section{DISCUSSION}

This study gives evidence that short-term water deprivation strongly influences a number of physiological and behavioral measures, including metabolic parameters of food ingestion, urination, and defecation. Among the factors that are depressed by water deprivation are the following: body weight, food intake, general activity, scent gland marking, facial grooming, urination, and defecation. There is also a decrease in scent gland size, which suggests that one of the physiological results of water deprivation is a reduction in androgen secretion (Thiessen \& Rice, 1976). The effects of water deprivation are completely reversed within 7 days when water is available.

Meriones unguiculatus, a species presumably subjected to periodic fluctuations in water availability (Bannikov, 1954), can live on water obtained from food metabolism for long periods of time (Winkelman \& Getz, 1962). Nevertheless, it is evident from this study that physiological and behavioral deficits result from even a few days of water deprivation. Yahr and Kessler (1975) have reported a marked long-term disruption of reproductive functions in the Mongolian gerbil even when lettuce was provided once a week. Production and survival of litters were almost completely depressed in the absence of water, and several secondary sex characteristics were below normal levels. Interestingly, reproductive abilities returned when the pairs were given as little as 10 to $60 \mathrm{~min}$ access to water daily. Clearly, gerbils are adversely affected by unavailability of water and cannot function normally.

Despite the wide range of consequences of water deprivation, there is no suggestion in this study that Harderianectomized gerbils are any more affected than intact gerbils. This is somewhat surprising in view of the dominant effect the Harderian gland has on hair pigments and lipids and because of the gland's apparent relationship to the pineal gland and the hypothalamus (Reiter \& Klein, 1971). It might be expected that the stress of water deprivation on metabolic processes or over longer periods of time would reveal a Harderian effect. Of course, other environmental challenges and physiological measures may uncover major systemic influences. At this point, however, it seems that the major functions of the Harderian gland are chemocommunication and production of hair pigments and lipids for the purpose of thermoregulation.

\section{REFERENCES}

Bannikov, A. G. The places inhabited and natural history of Meriones unguiculatus. In Mammals of the Mongolian Peoples Republic. Moscow: USSR Academy of Sciences, 1954.

KenNeDy, G. Y. Harderoporphyrin: A new porphyrin from the Harderian gland of the rat. Comparative Biochemistry and Physiology, 1970, 36, 21-36.

PAYNe, A. P. Pheromonal effects of Harderian gland homogenates on aggressive behavior in the hamster. Journal of Endocrinology, 1977, 73, 191-192.

REITER, R. J., \& KLE in, D. C. Observations on the pineal gland, the Harderian glands, the retina and the reproductive organs of adult female rats exposed to continuous light. Journal of Endocrinology, 1971, 51, 117-125.

Thiessen, D. D. Thermoenergetics and the evolution of pheromone communication. In J. M. Sprague \& A. N. Epstein (Eds.), Progress in psychobiology and physiological psychology. New York: Academic Press, 1977.

Thiessen, D. D., Clancy, A., \& Goodwin, M. Harderian pheromone in the Mongolian gerbil (Meriones unguiculatus). Chemical Ecology, 1976, 2, 231-238.

Thiessen, D. D., \& Kittrell, E. M. W. The Harderian gland and thermoregulation in the gerbil (Meriones unguiculatus). Physiology \& Behavior, 1980, 24, 417-424.

Thiessen, D. D., \& RiCE, M. Mammalian scent gland marking and social behavior. Psychological Bulletin, 1976, 83, 505-539.

Winkelman, J. R., \& Getz, L. L. Water balance in the Mongolian gerbil. Journal of Mammalogy, 1962, 43, 150-154.

YAHR, P., \& KESSLER, S. Suppression of reproduction in waterdeprived Mongolian gerbils (Meriones unguiculatus). Biology of Reproduction, 1975, 12, 249-254.

(Received for publication February 1, 1980; revision accepted March 10, 1980.) 